\title{
Flinders University
}

\section{Emily Sutherland}

\section{Historical Lives in Fiction, Characters in Fiction: Are they the same people?}

\author{
Abstract: \\ There is a strong relationship between history and fiction. The \\ characters created by writers, either in historical novels and literary \\ fiction, reflect that relationship. Many of the characteristics of fictional \\ characters can also be ascribed to characters depicted in historical \\ fiction and biographical writing.
}

How often, after reading a book, do we consider that we 'know' the characters? Readers may acknowledge that these characters are fictional, yet still think of them in some sense as real people. Since beginning to work on an historical novel in which the main characters are not fictional but based on three famous women, I came to wonder if, and in what ways, this differed from writing a novel where the characters are totally fictional. Specifically, if the characters we depict have already lived - historical characters - do they have a different identity from that of totally fictional characters? Following on from that, is there any difference between the act of portraying such characters in fiction or creating and developing a completely fictional character? These are two questions. I will begin with the question concerning identity using two examples.

The first concerns the day I saw Eileen. Eileen was born in 1945, in Melbourne, into a traditional Catholic family. She had a sister, Clare, and a brother, Jim. They were a close, comfortable, middle class family. Eileen attended the local Catholic school where she became sports captain and was a popular and lively student. Therefore her friends and family were astounded when she announced that, instead of going on to university, she would become a nun.

Eileen was very familiar to me but I had never seen her until the day I glanced across a room and noticed a woman. I had the feeling you get when you cannot quite put a name to a familiar face. Suddenly I realised that the woman I was looking at was Eileen. Almost immediately I recalled that Eileen was a character in Sisters, a novel I was then writing. The woman I was looking at could not have been Eileen because Eileen had never been a flesh and blood person.

The second example is from my current work in progress, a novel about three women who once lived. Each was famous in her lifetime and all have remained relatively famous up to the present time. Two of them, Hildegard of Bingen and Heloise, left written texts and letters. Of the third, Eleanor of Aquitaine, little of what she wrote remains but much remains of what was written about her.

We know something of their life stories, much of what they achieved and what their contemporaries wrote about them. In basing a novel on these three women I am embarking on fictional narrative, drawing on historical research, but not limiting myself 
only to what is accepted fact. Will the Heloise, Hildegard and Eleanor of my novel have identities separate from that of their actual lives? In what sense can we talk of them having an identity apart from the lives they actually lived?

In examining the concept of the identity of characters portrayed in a written text I have turned, not to literary criticism, but to philosophy. This seems particularly apt because one of the important characters in my novel, Abelard, is a philosopher, and the letters between him and Heloise include philosophical debate.

As a teacher of logic in the early twelfth century and a follower of Aristotle, Abelard was concerned with the nature and identity of individual things and universals. Constant Mews explains that:
Abelard's major theme is that all predicables are physical utterances of human imposition. Genus and species cannot be reduced to one very general being, as being (ens) is simply an ambiguous name, not a fixed category. A differentia is not a thing, but a word imposed to signify varying degrees of difference, whether making a species different from a genus or one individual of one species from another. When dealing with something that is whole (like a mortal, rational animal), these categories are words considered together, giving the reason why something is considered as a whole. A proprium [one's own peculiar characteristic] is a word imposed to signify what is peculiar to one thing rather than another. (Mews 2005: 33-34)

Put into terms that relate to my earlier question concerning the identity of characters within a written text, Abelard's theme can be used to say a person, who is alive, is a being. This being is unique and individual. All persons are classed as members of humankind. This means that all persons have a number of similar characteristics, which allow them to be classed within one classification. The identity of a person is his or her character. It is similar characteristics that allow all persons to be classified in the one group, but each person has an individual and recognizable character, which can be described by listing his or her characteristics. For example, Socrates is a man, with features in common with other men, but there is only one Socrates the philosopher. An individual's characteristics include appearance, age, social background, temperament, personality, education, motivation, capabilities and tendencies.

Others since Abelard have examined the nature of identity, including the nature of the identity of the fictional world that includes fictional characters. It is clear that in creating a fictional character, the writer necessarily calls on and describes many of the characteristics that pertain to living people. The difference between the living character and the fictional character is, however, more than the fact that one is (or has been) alive and the other is not. More importantly, one has a material presence, the other does not. A fictional character, in that sense, is an abstract concept. In creating a fictional character a writer may choose to describe as little or as many of the characteristics of the fictional character as seem appropriate. Some writers are more skilled than others in their creation of characters, so that we speak of a 'well rounded character', a 'developed character', 'stereotypes' or 'cut-out characters'.

But can any abstract concept ever be said to have an identity? Clearly there is a need to differentiate between a fictional world and the material world. Stacie Friend has defined differences in the theories of fictional reference as being between fictional-object theories and make-believe theories:

The fictional-object theories take our talk about fictional characters to involve genuine reference to real, usually nonexistent, objects of one sort or another ... [The] make-believe theory denies that there is a genuine reference to fictional objects. We pretend that there are such people, and then within the context of this pretence, but not outside it, we refer to them. (Friend 2000: 183-84) 
This means that we may either accept that fictional characters have no reality in the strictest meaning of the word 'real', but are creatures of our perceptions and imaginations in some sort of parallel world, or we may consider them as having a specific definable identity which relates, in some way, to our own world.

The extreme view is that fictional characters have no identity apart from empty names. A less extreme view allows them an abstract identity within the world of the imagination and, although they exist outside the material world, their identity is grounded in reality. A fictional character that has nothing in common with the characteristics of real people would not be credible. These characteristics need not include physical form, but the 'humanness' can still be recognized. Lewis Carroll's Alice's Adventures in Wonderland with a Cheshire cat and white rabbits is just one example.

Amie Thomasson, in Fiction and Metaphysics (1999) has postulated an approach which allows for the identification of fictional characters as abstract cultural artefacts after posing the question: if we postulated fictional objects, what would they be? A brief summary of her theory of Author Essentialism follows.

Fictional characters are ordinary, cultural, abstract artefacts, not inhabitants of a different realm. They come into existence only through the mental and physical acts of an author. These acts result in the production of literary works, created by a particular individual or group, at a particular time, in a particular social and historical circumstance. The fictional character can exist only as long as there are some individuals who have the language capacities and the background assumptions they need to read the literary text. Many different readers, on reading the same work, access the same fictional object. This means that fictional characters are not created afresh with each person's thinking of them. When the same character appears in different works, or is treated by different authors, the character is still the same cultural artefact, not separate or distinct. The identity of that character does not change with the individual reader's perceptions, in the same way that a living person does not have a separate identity for each person who meets him or her. It is the difference between perceptions and identity, a constructed reality or an objective reality. This is not a satisfactory explanation for those who do not accept that there is any objective reality, but that ranges far beyond the focus of this paper.

In Author Essentialism there are three elements that are necessary for the existence of a fictional character: the writer who creates the text, the actual text and the reader who has the capacity to understand that text. Remove any one of these elements and the fictional character ceases to exist. Thomasson explains the advantage of thus defining fictional characters:

By conceiving of fictional objects as abstract artefacts we can offer identity criteria for fictional objects both within and across literary works that not only are as clear and precise as those we have for ordinary objects but also correspond closely to our practices in treating fictional characters as the same or different. Moreover, the means employed to develop these identity conditions show the way for devising identity conditions for many other kinds of dependent objects, including the literary works on which the fictional objects depend. (Thomasson 1999: 55-56)

This statement accepts that characters portrayed in a literary text have some form of identity. Unless this is accepted, judgment of and discussion about such characters becomes impossible.

Thomasson's approach has special resonance for writers. She is looking at the identity of abstract concepts within a metaphysical context, using fictional characters as her model. Her conclusions give due weight to the creative role of the writer and the part played by the reader. Jeffery Goodman, in support of Thomasson, writes that:

... the causal origins of stories are essential properties of the story, so the dependence of the story on the author, and accordingly, the 
dependence of the fictional individuals mentioned therein on the author, is in fact an ontological dependence. (Goodman 2005: 207)

Thomasson has limited her discussion to fictional characters. Can her theory also be applied to historical characters in fiction? I put that question to her in an email, and received the following response:

I tend to think that we, in different contexts, want to speak about these cases in different ways. In some contexts (those I focus on in F\&M) it is important to note the author's reference back to the real world, to actual people, places and events, and we will speak about (the real) Nixon as appearing in (and re-characterized in certain ways in) a novel. In other contexts, though, e.g. if we are saying what a well-developed (or under-developed) character Nixon or Napoleon is in a novel, we seem to speak of it as we would of other purely fictional characters e.g. the Nixon-of-the-movie is sympathetically developed, etc. In those contexts of discussion, I think we can take ourselves to be referring to a created fictional character (the Nixon-of-the-movie; Napoleon-of-thenovel, etc.). (Thomasson 2005)

For me the significance of this reply is that it states that it is necessary to 'note the author's reference back to the real world', and that actual people may be thought of as 'appearing' in a novel. Thus, the historical character featured in a novel is a 'created fictional character' although one which relates to reality.

My fictional portrayals of Heloise, Hildegard and Eleanor rely heavily on doing research in the fields of medieval history and specifically the lives of the three women, and in reading fictional treatment of their lives in novels, plays, operas and films. In the numerous portrayals of Eleanor of Aquitaine in historical fiction there are a number of common characteristics, such as her difficult relationship with Louis VII, her love of music and her strength of character. Thus readers of any of these novels recognize that she is a specific person, not just a medieval queen. Similarly, any fictional representation of Heloise will refer to her relationship with Abelard and her scholarship. Hildegard of Bingen is not depicted in many books of fiction, but those that do refer to her visions, her love of nature, her life as a Benedictine nun and her music. Without at least some of these characteristics the character would bear scant resemblance to the historical Hildegard of Bingen.

Thomasson has defined fictional characters as abstract cultural artefacts and identified three elements upon which they depend. Even if some modification is required in applying her theory to historical characters in fiction, there is nothing in those three elements that apply exclusive to purely fictional characters and exclude historical characters.

Firstly, the character depends on the creative act of a particular author writing at a particular time and social context. Thus in creating an historical character within a literary text the person who is writing and the historical and social context in which he or she is writing are both extremely relevant to the way in which that character will be portrayed and developed. The achievements and identity of famous women have been reappraised in the light of feminist and gender studies. Over the centuries Heloise has been depicted as the ideal of a devoted lover, an intelligent woman who was dominated by Abelard, and a brilliant scholar whose literary works were received favourably while she lived, and which are still being rediscovered. In describing ways that biographers deal with Heloise's intellectual collaboration with Abelard, Juanita Ruys has identified four in particular:

The least flattering reading has Heloise as a flighty and attentionseeking woman, always anxious to engage the more serious Abelard in her frivolous requests ... Second, Heloise is presented as Muse to Abelard; that is as a woman who might inspire philosophical or theological reflections through passion or devotion or need, but not by intellectual interaction with him. 
Third there is the reading of Heloise as capable convent administrator, attentively considering her monastic situation and sending any resultant enquiries, problems or conclusions to Abelard, eliciting from him in return specific texts ... Finally there is the reading of Heloise as profoundly influencing Abelard's thought across the whole range of his writings ... (Ruys 1999: 60)

Yet within all these interpretations of Heloise there is a common thread, which acknowledges a close relationship with Abelard. It would be extraordinarily difficult to portray Heloise without including him.

The second element of Thomasson's theory refers to the production of a literary text. This text uses written words, usually on paper, published in some form. These words provide descriptions that are meaningful to a reader. There is no difference, in the physical production of a literary text, between one that features fictional characters and one that features historical characters. Finally, the individual reader may bring different experiences; knowledge and responses to a fictional or an historical character, but in appraising either type of character the reader will still consider him or her as a person.

The three elements Thomasson requires for the identity of a fictional character as an abstract cultural artefact can also be applied to historical characters in fiction. However there are other considerations in the portraying of historical characters. Writers of historical fiction have the freedom to exercise imagination, but within the confines of a credible scenario. My particular challenges are: to bring the three women to life for modern readers; to find a way to reconcile what I discover through research if it is at strong variance with accepted folk wisdom about these women; to decide how much freedom is allowed to fill in the gaps; and to work independently, with the sensation that historians are looking over my shoulder.

Given these constraints and limitations in writing historical fiction, might it not be preferable to eschew the practice? Patricia Dunker, in asking why any writer would choose to write historical fiction states that:

In the end all novels take on the mask of the historical novel as they step back from us into the past. So why do we write self-consciously historical fiction?... What indeed is history, so far as historical fiction is concerned? For every writer who attempts the project of remaking history must have, whether they are aware of it or not, a quite concrete notion of what history is, what it means, and what its ultimate significance must be to us, the past's inheritors. (Dunker 2002: 36-37)

And what Dunker has to say about writing historical novels applies to the portrayal of historical characters within those novels. Her answer as to why we find pleasure in both writing and reading historical novels is that they are 'an ideal form for conveying information, the sense of the landscapes, customs, objects, interiors, carrying us into another country of imagined worlds' (Dunker 2002: 39).

One of the constraints faced by writers of historical fiction is the conflict between what is learned through research, which may contradict common perceptions about a famous person in history. Until relatively recently it was fully accepted that Hildegard of Bingen was given to the Church by her parents when she was eight years old. It was arranged that she would be sequestered with Jutta, a holy young noblewoman, in a small stone cell adjoining the chapel at the abbey of St. Disibodenberg, with the expectation that they would live in that confined setting for the rest of their lives. In modern parlance this action by her parents would be regarded as child abuse. In medieval times giving a child to the monastery was religious insurance for both the child and her family.

Recent discovery of a document purported to be a contemporary biography of Jutta contradicts this version. According to this account, from the age of eight when her parents first gave her to the Church, until she turned fifteen, Hildegard lived with Jutta on a large estate, being cared for and guided by a noble widow. Jutta and Hildegard were not 
enclosed in the small stone enclosure, which abutted the abbey chapel, until Hildegard was fifteen years old.

The first version of Hildegard's life has greater dramatic narrative potential, and is the one with which people would be familiar. The second version may explain Hildegard's knowledge of medicine and natural phenonema revealed through her scientific writing. Must I, as a writer, make a scholarly decision as to which version is most strongly supported by the evidence and accept it; or may I, in my fictional account, choose that version which most satisfactorily drives my creative vision?

Let me give another example of potential conflict between what has been universally accepted, and what further research may reveal. Recently I was in France where I visited the abbey of St Denis, where Abelard had entered as a monk, and then Argenteuil, where the abbey that Heloise had entered was situated. What struck me quite forcibly, while actually there, was how close the two sites are. It would have been quite an easy journey down the river for Abelard to visit Heloise. Did Abelard choose to enter St Denis because it was a very prestigious abbey near Paris, and one where he would have the support of the powerful Abbot Suger? Once he was there did he concentrate solely on resurrecting his career and reputation, shunning all contact with Heloise? Or did he choose St Denis so that he could maintain contact with Heloise? If the latter did he visit her often in those first years of their separation? Did she visit him? He loved her and was her husband; it is plausible that he wished to be near her, to guide and protect her. This is a new consideration, and a romantic one, expunging the image of Abelard as the selfish egotist who ruined Heloise's life and then abandoned her to emotional barrenness.

If I accept the softer Abelard I am robbed of a possibly bitter and cynical Heloise. The idea of their keeping in close contact throughout their entire lives, on the other hand, gives me the opportunity to portray their relationship in a very different way to that normally presented. Which version most fits the way I wish to portray Heloise? Either version - a neglected or an emotionally supported Heloise - have narrative possibilities. As a writer of fiction I may choose either interpretation. Unfortunately I cannot have both!

This brings me back to the second question posed at the beginning of this paper. If historical characters in fiction have a strong relationship to their known life story can the portrayal of them be judged as a creative act? Is my portrayal of Eileen, a totally fictional character, achieved through a different process from that to be used in my portrayals of Heloise, Hildegard and Eleanor? Perhaps, in Eileen, I was creating a character, but in Heloise, Hildegard and Eleanor I am only rewriting history.

There is a difference between historical people portrayed by historians and biographers and those by fiction writers. This difference is the subject of debate and contention between historians, biographers and novelists. Think of a spectrum. On the left are totally fictional characters (TFC). On the right are accounts of people written by historians (HA). Nearer the centre, but still on the right, are the subjects of biographies (B). Historical characters in fiction (HCF) are placed near centre left between biography and fiction.
TCF
$\mathrm{HCF}$
B
HA

Characters as Fiction

Those writing nonfiction regard fiction as having the potential to be a distortion of the facts, if not a total fabrication. Not all historians are as accommodating to the fiction writer as is Ruys, who sees a positive role for the novelist. Ruys, in studying the representation of Heloise in the twentieth century concluded that biographies have their limitations, which include focusing exclusively on the facts and eschewing speculation 'in 
order to safeguard its place on the academic side of the fact/fiction divide.' She suggests that the historical novel is one solution to the problems imposed by biography:

\begin{abstract}
Novelists have a generically-sanctioned ability to pause and consider issues and to apply imagination to their subject's life. If they also choose to write consonant with the demands of authenticity, they may do so with humour, insight and compassion. It may be that this combination of imagination and authenticity produces as nuanced and holistic a picture of a female figure as could be found in any genre. (Ruys 1999: 225)
\end{abstract}

This supports the notion that while historical characters are based on people who really lived, in writing fiction there is not only a place but also a need for the writer's imagination and creativity.

An interesting comparison can be made with artists. One artist paints a portrait of a living person, while a second artist paints a picture of a person whom he imagines. While they may differ in style or merit, the subject matter would be regarded as the same in so far as they are both portraits of a person. The painter who portrays an imagined person may base that portrayal on a particular but unnamed person, or may draw on a composite image of people he or she has seen. Consider Pieter Breughel for example, whose genre pictures of peasant life featured distinctive individual figures that may or may not have been based on actual people. In the same way, writers creating characters draw on themselves, on specific people they have known or on their observations, even when portraying fictional characters.

One may also make a distinction between a photograph of a living person and a portrait. The art of photography may highlight facets and aspects of a face or figure, but the subject is still a real person. Models may dress up as famous people, but this becomes a representational/biographical portrait. No would imagine now that a man resembling Abraham Lincoln and dressed in the fashion of his time was the real Abraham Lincoln.

Let us return to my three wonderful women, Heloise, Hildegard and Eleanor. To bring them to life for the modern reader I need to portray them as believable people, reveal their personalities, give some idea of their appearance, and relate my narrative to events in their lives. For the reader the historical characters I create may be no more or no less 'real' than a fictional character.

Perception of identity rests strongly on appearance. Some biographers may refer to Hildegard of Bingen as being beautiful, but there is nothing elsewhere to suggest physical beauty; nor is this particularly relevant when writing about a woman who is famous for her achievements, not her looks. From all I have read by and about her I imagine her as short and dumpy but with a wise and kindly face. There are no reliable portraits of Hildegard, so my references to her physical appearance, part of her identity, rely upon my perceptions derived from my studies, reading and listening to her music.

Heloise also suffers from a lack of portrait or detailed description. Abelard describes her as being: 'in looks not ranked the lowest' (Abelard 1974: 66). Most of the writers who tell her story within an historical novel describe her as being very beautiful, consistent with the stereotype of a romantic heroine. My own feeling is that she had a face made attractive more by her intelligence and animation than physical features. Her personality comes through so clearly in her letters to Abelard, giving such a strong sense of her unique character that her personal appearance almost seems irrelevant.

Even Eleanor, an acknowledged beauty, left us no portrait. In fact the only known description of her is by Bernard of Clairvaux who was so incensed by her rich clothes and jewellery that he forgot to mention her features or colouring. He likened her to:

One of those daughters of Belial, who, got up in this way, put on airs, walk with heads high and mincing steps, their necks thrust forward, and, furnished and adorned as only temples should be, they drag after 
A researcher would be inclined to judge that Bernard's description is unnecessarily harsh, and treat it with great caution.

Writers' imaginations are instructed and stimulated by their research, but it cannot then be assumed that all the accounts found in primary or secondary sources faithfully depict a person. Such descriptions may be coloured by politics, gender, malice or admiration. We do not even know the colour of Eleanor's hair, nor her eyes. She wore a rich scarlet dress when she married Louis VII, which suggests to me that she was a strong and confident woman, although it might just have been the year for being married in scarlet.

In the case of Heloise and Hildegard we can learn a great deal from their writings. Eleanor left only some official documents that reveal little. History tells us much about what she did, where she travelled, her conflicts with both husbands and her efforts to ensure that the children she had with Henry obtained their estates and kingdoms. Through all of this, her physical presence and personality can be developed and used as the basis to create her character within my novel.

I can research the writings of my three women, read accounts by contemporaries, and subsequent academic papers, as well as biographies and historical novels and while from these I glean and reap, the final depiction of the women is my harvest.

Would I do it differently if I were writing about three fictional women? I would need to set them in an historical context, even if it were a contemporary one, the 'imaginary world' to which Dunker refers. I would need to describe their appearance, personalities and actions, and before I could do that I would have to reach some conclusions concerning all three aspects. I would need to show how they perceived themselves and how others reacted to them. I would have greater freedom in choosing certain details in this process of creation, but there would still be the need for research to ensure that the fictional world and characters that I created were credible. I maintain that the process of writing Heloise, Hildegard and Eleanor is essentially the same as it would be were I creating three completely fictional women. What is different is the means of compiling the background and salient information about the characters. In writing an historical character in fiction we start with a known facts, which provide a springboard for the imagination to fill in the many gaps.

To illustrate the point about the similarity between the identity of fictional and historical characters in a literary text I would ask you to imagine a biography, complete with references, letters and reports of interviews with friends and family. The subject of this biography does not exist. The references, letters and accounts of interviews with friends and family are totally fabricated. In other words this 'biography' is a work of fiction. The subject of this biography, although ostensibly a person who once lived, is a fictional character. The information used to describe such a character resembles those one would use to invent a fictional character- background, setting, physical form, personality and relationships with others. The writer has drawn on his or her imagination and inventiveness to create this character. The only difference is that the character is presented in a format normally used for biographical writing rather than in a novel. While this may be considered an argument about genre rather than historical fiction it also supports my point that the process of creating a character based on a person who lives, or has lived, is similar to that of planning, developing and writing a fictional character.

In using the lives of Heloise, Hildegard and Eleanor there is a framework of historical period and the circumstances of their lives. This is not negotiable unless I am prepared to sacrifice verisimilitude. Where there is an opportunity to use imagination and insight is in according reactions and motivation to these women.

For example, Hildegard's visions have been variously ascribed to: a visit from God, migraine or psychosis (see Maddocks 2002: 61-64). A writer's version of Hildegard's personality will be coloured by the acceptance of any of these interpretations. The writer is also free to reject all of them and interpret the visions in some other way. Or take 
Eleanor: how did she feel as a young woman coming to the stricter Royal Court in Paris after the freedom of her household in Aquitaine? How was she affected by the death and carnage she witnessed during the Crusades? Did she choose to marry Henry because he was a lusty, attractive man, even if he was some years her junior, or was she influenced by his prospects and estates? Would a hard-headed practical woman, such as Eleanor must have been to survive the intrigues and machinations of court life in both France and England, have been concerned with Courts of Love? Finally consider Heloise: did her feelings towards Abelard change after she read his letter 'Historia calamitatum' in which he attributed their earlier love relationship, one that had remained the focus of her thoughts for many years, as being solely his yielding to his lustful and sinful desires? We know what she wrote in reply as we have copies of the correspondence between these two, but letters were a more public matter in the Middle Ages, written with the expectation that others might read them. Is it possible to look beyond this official correspondence to imagine how a woman might really react in such circumstances? It is in such considerations, which are both a challenge and a delight for any writer, that the creative process is stimulated and nurtured.

A definition of the identity of fictional characters, such as Thomasson's, provides a basis for literary criticism, and textual analysis. To extend that definition to include historical characters is justified. The requirements of good writing - an overarching theme, satisfying narrative, character development, and a text that is thought provoking and stimulating - still apply in either case. While the writer of historical fiction has a responsibility to respect the truth as far as it is known, it is in taking the story beyond what is known that creativity is called into play. Part of that creative process is the creation and depiction of the historical character in the novel.

Writers of historical fiction need to be able to connect with people who lived some time ago, in order to then connect these people to modern readers. A firm base of historical knowledge and judgement is essential to negotiate modern perceptions and societies and interpret past cultures. Within these considerations the identity of an historical character in fiction or a fictional character can be defined in a similar way. The same process, using knowledge, imagination and word pictures, is required to create either of these categories. However, if the historical character in a fictional text is to relate credibly to the person on whom it is based, the writer is constrained in particular ways in the use of knowledge and imagination. By the same token the writer will need to develop the narrative and develop the characters to create a story that holds the reader's interest. Accepting that the historical character does share many of the characteristics of a fictional character is a helpful step in the creative process.

\section{List of works cited}

Abelard, Peter 1974 'Historia Calamitatum', in Letters of Abelard and Heloise (trans Betty Radice), London: Penguin Books return to text

Dunker, Patricia 2002 Writing on the Wall, London: Pandora return to text

Friend, Stacie 2000 'Real People in Unreal Contexts' in Anthony Everett and Thomas Hofweber (eds) Empty names, fiction and the puzzles of non-existence, Stanford: CSLI Publications, 183-203 return to text

Goodman, Jeffery 2005 'Defending Author Essentialism', Philosophy and Literature, vol 29/1, April, 200208 return to text

Maddocks, Fiona 2002 Hildegard of Bingen: The Woman of her Age, London: Headline Book Publishing return to text

Mews, Constant 2005 Abelard and Heloise, New York: Oxford University Press return to text

Ruys, Juanita Feros 1999 Genre, Gender and Authenticity: Readings of Heloise in the Twentieth Century (unpublished doctoral thesis), University of Sydney, Department of English p.60 return to text

Thomasson, Amie 2005 personal email, 5 December return to text 
Thomasson, Amie 1999 Fiction and metaphysics, Cambridge: Cambridge University Press return to text

Weir, Alison 1999 Eleanor of Aquitaine, London: Pimlico return to text

Emily Sutherland is in the third year of a PhD in Creative Writing at Flinders University of South Australia, having completed the Master of Creative Arts in 2004. Currently she is teaching 'Introduction to Creative Writing' at Flinders University.

\section{TEXT}

Vol 11 No 1 April 2007

http://www.griffith.edu.au/school/art/text/

Editors: Nigel Krauth \& Jen Webb

Text@griffith.edu.au 